\title{
Purification of Phycocyanin from Chaohu Algae by Various Salting out Methods
}

\author{
Kolawole B. H. E Boni* , Fayu Zhang, Wu Kang, Jiaquan Wang \\ Hefei University of Technology \\ *Corresponding author: Hananiaboni@gmail.com
}

Received November 14, 2018; Revised December 27, 2018; Accepted January 14, 2019

\begin{abstract}
This research was carried out to extract and purify phycocyanin from blue algae in Chaohu Lake by utilizing salting out methods. Thus a two-step salting out was performed using Ammonium sulphate, Triammonium citrate, Sodium citrate and Sodium sulfate. The phycocyanin and the impurity solution collected at each phase were subjected to analysis by using UV-Vis spectrophotometer to identify the optimal dose of ammonium sulfate, triammonium citrate, sodium citrate and sodium sulfate. The optimal molar concentration for Ammonium sulphate, Triammonium citrate, Sodium citrate and Sodium sulfate in the first and second salting out process were $1.0 \mathrm{~mol} / \mathrm{L}$ and $1.7 \mathrm{~mol} / \mathrm{L}$ for Ammonium sulphate $\left(\mathrm{NH}_{4}\right)_{2} \mathrm{SO}_{4}, 0.7$, mol/L and $1.3 \mathrm{~mol} / \mathrm{L}$ for Triammonium citrate $\mathrm{C}_{6} \mathrm{H}_{17} \mathrm{~N}_{3} \mathrm{O}_{7}$, $0.5 \mathrm{~mol} / \mathrm{L}$ and $0.9 \mathrm{~mol} / \mathrm{L}$ for Sodium citrate $\mathrm{C}_{6} \mathrm{H}_{5} \mathrm{Na}_{3} \mathrm{O}_{7}, 1.0 \mathrm{~mol} / \mathrm{L}$ and $1.3 \mathrm{~mol} / \mathrm{L}$ for Sodium sulfate $\mathrm{Na}_{2} \mathrm{SO}_{4}$. $\mathrm{After}$ the two-step salting out processes, it was observed that higher molar concentrations can remove impurities in large quantities, and both purity and yield was greatly increased. The results indicate a purity of phycocyanin above 2.0 with a phycocyanin recovery relatively high. This was carried out to affirm and estimate if the result from the salt use will vary from a previous experiment carried out on the same river by the authors with three (3) different kinds of salt $\mathrm{K}_{3} \mathrm{C}_{6} \mathrm{H}_{5} \mathrm{O}_{7} \mathrm{H}_{2} \mathrm{O}, \mathrm{C}_{6} \mathrm{H}_{5} \mathrm{O}_{7}\left(\mathrm{NH}_{4}\right)_{3}$ and $\left(\mathrm{NH}_{4}\right)_{2} \mathrm{SO}_{4}$ as compared to the four (4) salt compound used in this experiment.
\end{abstract}

Keywords: cyanobacteria, phycocyanin, purity, salting-out, yield

Cite This Article: Kolawole B. H. E Boni, Fayu Zhang, Wu Kang, and Jiaquan Wang, "Purification of Phycocyanin from Chaohu Algae by Various Salting out Methods.” World Journal of Environmental Engineering, vol. 6, no. 1 (2019): 1-6. doi: 10.12691/wjee-6-1-1.

\section{Introduction}

Kinbria G [1] stipulated that cyanobacteria is one of the longest life form on earth. This assumption was also captured in the work of [2]. They stated in their study that cyanobacteria could be classify as the world primitive life form. Cyanobacteria contains chlorophyll, carotenoids and phycobiliproteins. PBPs are soluble supramolecular protein combination engaged in photosynthesis and may contain as much as $40 \%$ to $60 \%$ of the total soluble protein $[3,4]$. Phycobiliproteins could further be classified into three categories, depending on their properties or characteristics. These categories are Phycoeryhrin (kmax-565 nm), allophycocyanin (kmax-650 nm) and (kmax-620 nm) phycocyanin [5,6,7]. The foundation of phycopiliprotein consists of different polypeptides chains $(\alpha \beta)$ [8], belonging to two categories ( $\alpha$ and $\beta$ ) probably derived from a common descendent or root, but other researchers such as Apt, K.E, Collier, J.L.; Grossman, A.R [9] believes that the two categories of phycopiliprotein may be a divergence from the root through evolution. Phycobiliproteins consist of two diverse polypeptides namely $\alpha$, (MW-12-19 $\mathrm{kDa})$ and $\beta$, (MW-14-21 kDa) [10]. Cyanobacterial phycocyanin (C-PC) is the most significant phycobiliprotein within blue-green algae. According to Sekar, S.; Chandramohan [11]; Qureshi, M.A.; Garlich, J.D., \& Kidd, M.T., [12]; Romay, C.; Gonzalez, R [13]. Phycocyanin in PBPs is widely used as anti-inflammatory agent, nutritional ingredient, natural dyes, florescent markers, pharmaceuticals and antioxidants. Phycocyanin can also be utilized as colorant in consumable products and cosmetics, such as lipstick and eye liners etc. Cherng, Cheng, Atarn [14]; Eriksen [15]; Chaiklahan, R.; Chirasuwan, Loha, Tia, Bunnag, B [16]; Kuddus, M.; Singh, P.; Thomas, G.; Al-Hazimi, A [17]; Sonani, R.R.; Singh, N.K.; Kumar, J.; Thakar, D.; Madamwar [4] also confirmed in their research, that phycocyanin contains therapeutic significance (immuno-modulation activities and anti-cancer activities). Because of fluorescence and antioxidant characteristics of cyanobacterial phycocyanin, broad arrays of applications of phycobiliproteins are possible [18] particularly in biomedical research, diagnostics and therapeutics; $[19,20]$. Cyanobacteria, a potential source of phycocyanin, have been exploited for quite a long time. However, most investigations have predominantly centered on the production and purification of phycocyanin from Spirulina platensis $[21,22,23,24]$. The current research has established the functions of cyanobacterial phycocyanin in hepatoprotective [25], antioxidant [25,26], free radical scavenger [26] and anti-inflammatory [25,27,28]. Each 
micro-organism has special characteristics that produce proteins, indicating that the molecule in question may be found in the cytoplasm or periplasm and even be stored in some cellular organelle, such as the mitochondria. In this regard, extraction protocol could be different according to the preferred protein. The development of modus operandi or approaches for effective purification of cyanobacterial phycocyanin has been an indispensable pre-requisite for advancements made in the field of biotechnology. The key to effective cyanobacterial phycocyanin purification involves choosing a suitable method to optimize their performance in order to meet the require standard and also combine them in a reasonable way for the purpose of maximizing performance and minimizing the number of steps required. Various approaches have been reported for effective purification of cyanobacterial phycocyanin, but all these reported approaches rivet the amalgamation of diverse techniques such as centrifugation, dialysis, ammonium sulfate precipitation, hydroxyapatite, ion exchange chromatography, double water phase, gel permeation chromatography, and expanded bed adsorption chromatography [29]. As stated by Niu, Wang, Tseng, [30], the extraction method is utilized as the utmost recovery technique for extracting phycobiliproteins in it raw state from algae. Phycobiliproteins extraction consists of bursting of cells and releasing proteins from the busted cell. The cell walls of cryptophytes are fragile as compared to cyanobacteria which are extremely defiant [31]. In this study work, two steps of salting out method were used for the purification of C-Phycocyaninfrom Chaohu Lake, using Ammonium sulphate, Triammonium citrate, Sodium citrate and Sodium sulfate. This study has been carried out in Hefei city in Anhui province, in the People's Republic of China in 2018.

\section{Materials and Methods}

\subsection{Organism and Culture Conditions}

The micro-organisms in the study are the fresh algae (Cyanobacteria) from Hefei Binhu District, Huhu Lake Road, Chaohu Lake which grows during summer at about 30 degrees.

\subsection{Laboratory Equipment}

The laboratory equipments used for the study were; UV-Vis spectrophotometer type UV/VIS-1950 (Beijing Puzhou General Company); Thermostatic stirrer, type 85-2A (Jiangsu Jincheng Guosheng Instrument Factory); Low temperature and high speed centrifuge, type KDC-160HR (Anhui Zhongjia Zhongjia instrument company) and Freezer; model BC/BD-718DTF (Tianchang Tianyi Electric Appliance Co., Ltd.);

\subsection{Phycobiliprotein Extraction and Purification}

\subsubsection{Preparation of Phycocyanin Crude Extract}

Cyanobacterial mud from Chaohu Lake were weighed, and the phosphate buffer $(0.01 \mathrm{~mol} / \mathrm{L}, \mathrm{pH} 7.0)$ was added according to the ratio of material to liquid $1: 5$, then a freeze-thaw process was repeated three times. The Supernatant fluid passed through four layers of ordinary gauze. The resultant slurry was centrifuged at $8,000 \mathrm{~g}$ for $20 \mathrm{~min}$ to remove the cellulose and cell impurities.

\subsubsection{Precipitation Method}

The whole procedure was carried out at $4^{\circ} \mathrm{C}$, based on the method provide by [32]. The molar concentration added to the crude extract is as follow:

- Concentration of Ammonium sulphate $\left(\mathrm{NH}_{4}\right)_{2} \mathrm{SO}_{4}$ added to the crude extract was $0.2,0.4,0.6,0.8,1.0$, $1.2 \mathrm{~mol} / \mathrm{L}$ respectively.

- Concentration of Triammonium citrate $\left(\mathrm{C}_{6} \mathrm{H}_{17} \mathrm{~N}_{3} \mathrm{O}_{7}\right)$ added to the crude extract was $0.4,0.5,0.6,0.7,0.8$ and $0.9 \mathrm{~mol} / \mathrm{L}$ respectively.

- Concentration of Sodium citrate $\left(\mathrm{C}_{6} \mathrm{H}_{5} \mathrm{Na}_{3} \mathrm{O}_{7}\right)$ and added to the crude extract was $0.3,0.4,0.5,0.6,0.7$ and $0.8 \mathrm{~mol} / \mathrm{L}$.

- Concentration of Sodium sulfate $\left(\mathrm{Na}_{2} \mathrm{SO}_{4}\right)$ added to the crude extract was $0.95,1.0,1.05,1.10,1.15$ and $1.20 \mathrm{~mol} / \mathrm{L}$.

The crude extract was centrifuged at 8,000g for $20 \mathrm{~min}$ and after the static incubation; the purity ratio of phycocyanin in the supernatant was measured by UV-Vis spectrophotometer.

According to the experimental results, the optimal conditions for phycocyanin extraction were selected. The molar concentration added to the supernatant was further increased as follow:

- Concentration of Ammonium sulphate $\left(\mathrm{NH}_{4}\right)_{2} \mathrm{SO}_{4}$ was increased to $1.3,1.4,1.5,1.6,1.7$ and $1.8 \mathrm{~mol} / \mathrm{L}$, respectively.

- Concentration of Triammonium citrate $\left(\mathrm{C}_{6} \mathrm{H}_{17} \mathrm{~N}_{3} \mathrm{O}_{7}\right)$ was increased to $1.0,1.1,1.2,1.3,1.4$ and 1.5 $\mathrm{mol} / \mathrm{L}$, respectively.

- Concentration of Sodium citrate $\left(\mathrm{C}_{6} \mathrm{H}_{5} \mathrm{Na}_{3} \mathrm{O}_{7}\right)$ was increased to $0.7,0.8,0.9,1.0,1.1$ and $1.2 \mathrm{~mol} / \mathrm{L}$, respectively.

- Concentration of Sodium sulfate $\left(\mathrm{Na}_{2} \mathrm{SO}_{4}\right)$ was increased to $1.2,1.3,1.4,1.5,1.6$ and $1.7 \mathrm{~mol} / \mathrm{L}$, respectively.

The supernatant was centrifuged at $8,000 \mathrm{~g}$ for $20 \mathrm{~min}$. The precipitate was washed with phosphate buffer $(20 \mathrm{mM}$, $\mathrm{pH} 7.0)$.

\subsection{Main Analysis Methods}

Phycocyanin at $620 \mathrm{~nm}$ has a characteristic absorption peak, while protein has maximum absorption peak at 280 $\mathrm{nm}$. The purity of phycocyanin was measured by using the formula recommended by [33]. The phycocyanin mass concentration and recovery rate was measured using the Eqs. 1 to 3, as recommended by [29].

Phycocyanin purity:

$$
P=A 620 / A 280
$$

Phycocyanin mass concentration(g/L):

$$
[P C]=\left(A_{620}-0.7 \times A_{650}\right) / 7.38
$$

Recovery of phycocyanin (\%):

$$
R=100([P C] \times V t) /\left([P C]_{0} \times V_{0}\right)
$$


Where, A280, A620 and A650 respectively represent the absorbance at the wavelength of 280, 620 and 650nm, Vt stands for phycocyanin volume, $[\mathrm{PC}]_{0}$ is the mass concentration of phycocyanin crude extract and $\mathrm{V}_{0}$ is the volume of crude extract from phycocyanin.

\section{Results and Discussion}

\subsection{Ammonium Sulfate Precipitation}

\subsubsection{One Step Salting out}

In the range of $0.2 \sim 1.2 \mathrm{~mol} / \mathrm{L}\left(\mathrm{NH}_{4}\right)_{2} \mathrm{SO}_{4}$ concentration, a one-step salting out process was performed according to the precipitation method, to determine the purity and the yield of phycocyanin in the supernatant as shown in Figure 1.

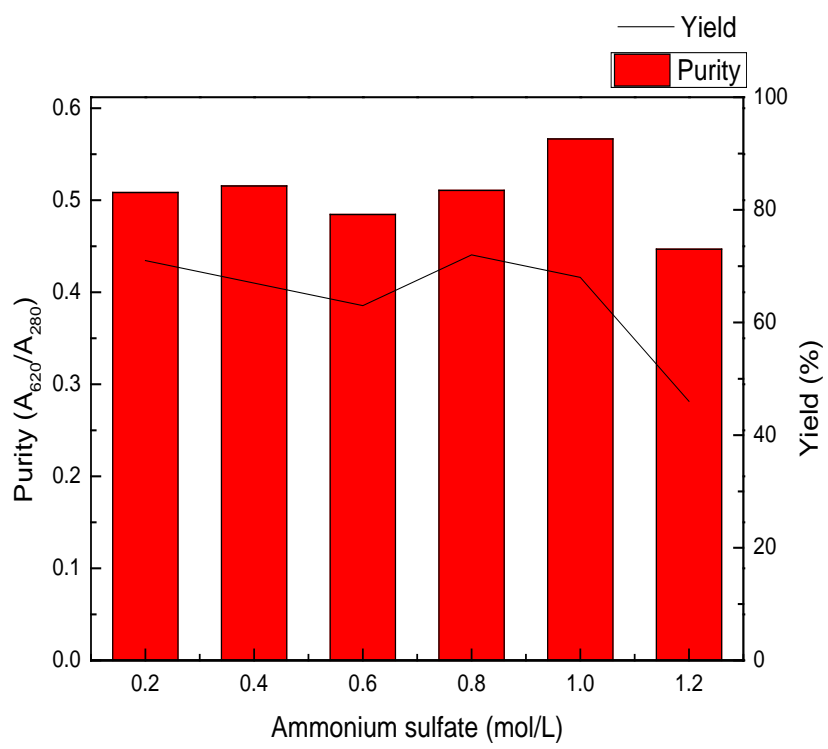

Figure 1. Effect of molar concentration of ammonium sulfate on purity and yield of C-phycocyanin

In the range of $0.2 \sim 0.8 \mathrm{~mol} / \mathrm{L}$, the purity remained almost unchanged, and the yield showed a slow downward trend between 0.2 and $0.6 \mathrm{~mol} / \mathrm{L}$ and a slow upward trend from 0.6 to $0.8 \mathrm{~mol} / \mathrm{L}$. When the concentration was equal to $1.2 \mathrm{~mol} / \mathrm{L}$, both the purity and the yield were decreased. The purity of phycocyanin reached the maximum value of 0.5666 with $68 \%$ of yield when the concentration was equal to $1.0 \mathrm{~mol} / \mathrm{L}$. The optimal conditions for the extraction of phycocyanin were $1 \mathrm{~mol} / \mathrm{L}$.

\subsubsection{Two Step Salting out}

On the basis of one-step salting process, in the range of $1.3 \sim 1.8 \mathrm{~mol} / \mathrm{L}\left(\mathrm{NH}_{4}\right)_{2} \mathrm{SO}_{4}$ concentration, the experiment was carried out in accordance with the precipitation method to obtain phycocyanin precipitation, through dissolution and todetermine the purity and yield of phycocyanin as shown in Figure 2.

In the range of $1.3 \sim 1.8 \mathrm{~mol} / \mathrm{L}$, the purity of phycocyanin in the precipitation increased first and then decreased while the yield in the precipitation showed an upward trend with a slow downward trend between 1.6 and $1.7 \mathrm{~mol} / \mathrm{L}$. At $1.7 \mathrm{~mol} / \mathrm{L}$, the purity of phycocyanin reached the maximum value of 2.0 while, the yield was
35\%. Hence the optimal conditions for phycocyanin extraction stood at $1.7 \mathrm{~mol} / \mathrm{L}$.

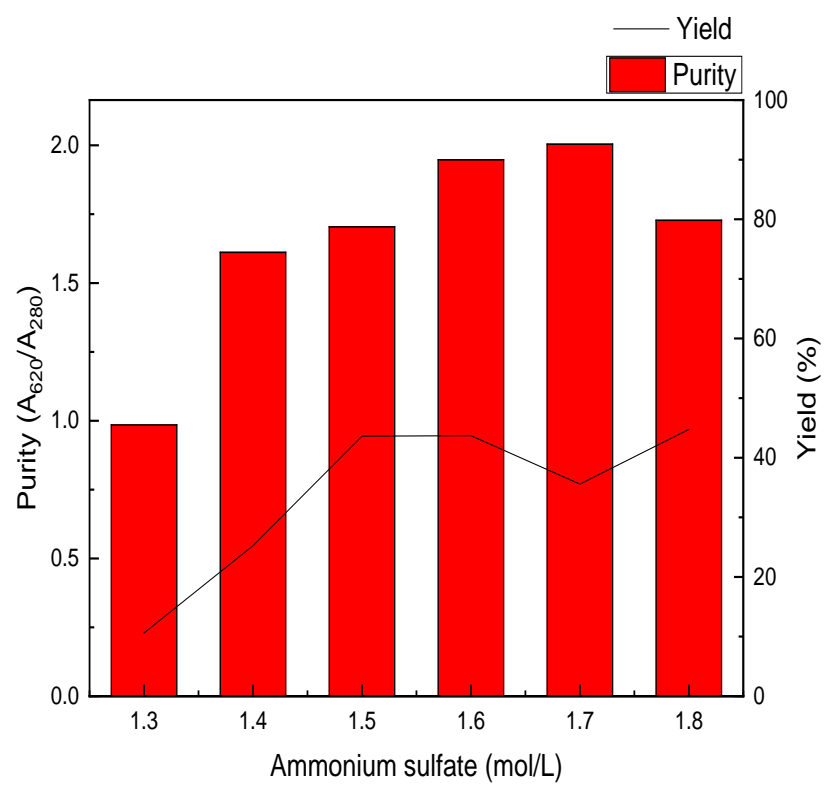

Figure 2. Influence of different molar concentration of ammonium sulfate in the two-steps salting-out on purity and yield of phcocyanin

\subsection{Triammonium Citrate}

\subsubsection{One-step Salting out}

In the range of $0.4 \sim 0.9 \mathrm{~mol} / \mathrm{L} \mathrm{C}_{6} \mathrm{H}_{17} \mathrm{~N}_{3} \mathrm{O}_{7}$ concentration, a one-step salting out process was performed according to the precipitation method to determine the purity and the yield of phycocyanin in the supernatant as shown in Figure 3.

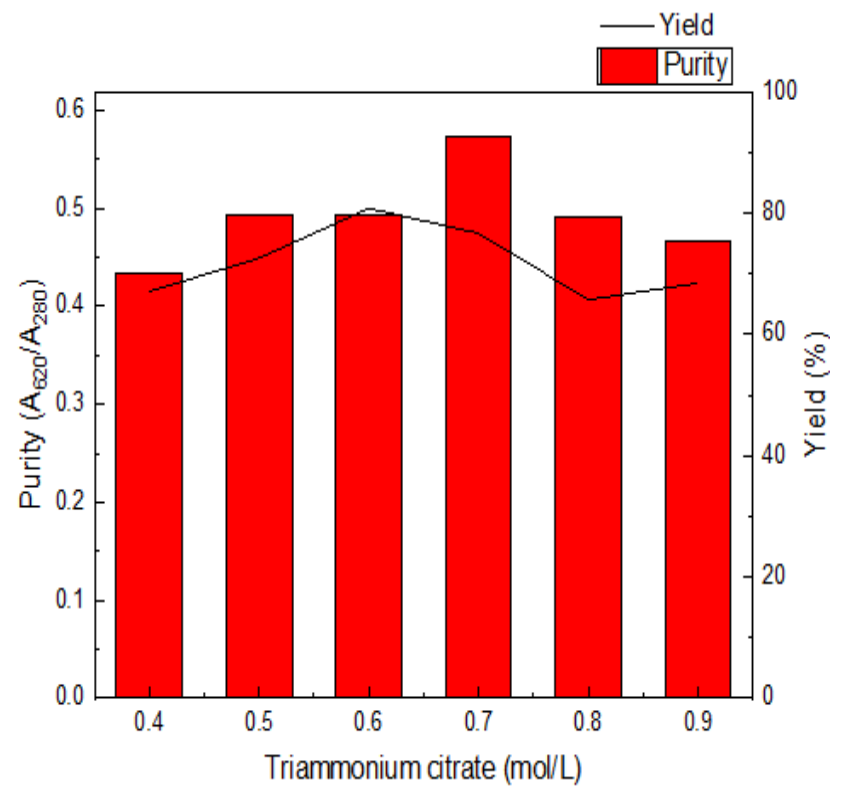

Figure 3. Effect of molar concentration of Triammonium citrate on purity and yield of C-phycocyanin

In the range of $0.5 \sim 0.6 \mathrm{~mol} / \mathrm{L}$ and $0.8 \sim 0.9 \mathrm{~mol} / \mathrm{L}$, the purity remain almost unchanged. When the concentration was equal to $0.7 \mathrm{~mol} / \mathrm{L}$, the purity of phycocyanin reached the maximum value of 0.573 with a yield of $76 \%$. Resulting in an optimal condition for PC extraction at $0.7 \mathrm{~mol} / \mathrm{L}$. 


\subsubsection{Two-step of Salting out}

On the basis of one-step salting process in the range of 1.0 1.5 mol/ $\mathrm{L} \mathrm{C}_{6} \mathrm{H}_{17} \mathrm{~N}_{3} \mathrm{O}_{7}$ concentration, the experiment was carried out in accordance with the purification method to obtain phycocyanin precipitation through dissolution and determine the purity and yield of phycocyanin as shown in Figure 4.

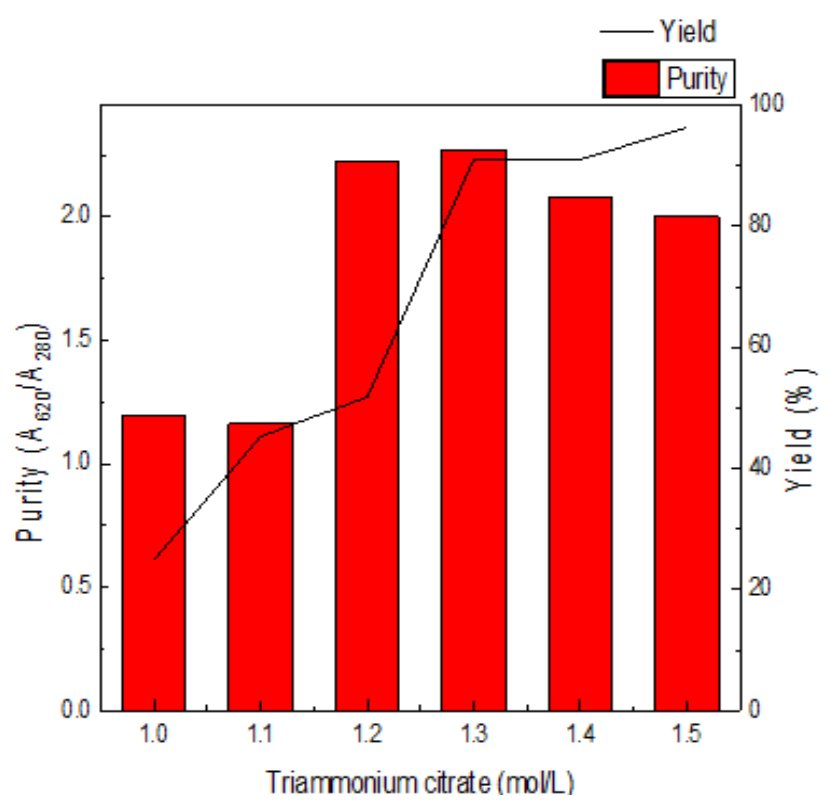

Figure 4. Influence of different molar concentration of Triammonium citrate in the two-step salting-out on purity and yield of Phcocyanin

Between 1.0 1.1 mol/L, the purity was very low. At the range of $1.2 \sim 1.5 \mathrm{~mol} / \mathrm{L}$ the purity highly increased and then decreased slowly while the yield has an upward trend. The purity was at a maximum value of 2.27 at $1.3 \mathrm{~mol} / \mathrm{L}$ with a yield of $91 \%$. Consequently, the optimal conditions for phycocyanin extraction were $1.3 \mathrm{~mol} / \mathrm{L}$.

\subsection{Sodium Citrate}

\subsubsection{One-step of Salting out}

In the range of $0.3 \sim 0.8 \mathrm{~mol} / \mathrm{L} \mathrm{C}_{6} \mathrm{H}_{5} \mathrm{Na}_{3} \mathrm{O}_{7}$ concentration, a one-step salting out process was performed according to the precipitation method to determine the purity and the yield of phycocyanin in the supernatant as shown in Figure 5.

At the concentration of $0.3 \sim 0.5 \mathrm{~mol} / \mathrm{L}$, both the purity and yield of phycocyanin were basically unchanged, but within the range of $0.6 \sim 0.8 \mathrm{~mol} / \mathrm{L}$ both declined very quickly. When the concentration was equal to $0.5 \mathrm{~mol} / \mathrm{L}$, the purity of phycocyanin reached the maximum value of 0.6234 and the yield of phycocyanin was 98\%, producing an optimal condition for PC extraction at $0.5 \mathrm{~mol} / \mathrm{L}$.

\subsubsection{Two-step of Salting Out}

On the basis of one-step salting process in the range of $0.7 \sim 1.2 \mathrm{~mol} / \mathrm{L} \mathrm{C}_{6} \mathrm{H}_{5} \mathrm{Na}_{3} \mathrm{O}_{7}$ concentration, the experiment was carried out in accordance with the purification method to obtain phycocyanin precipitation through dissolution and determine the purity and yield of phycocyanin as shown in Figure 6.

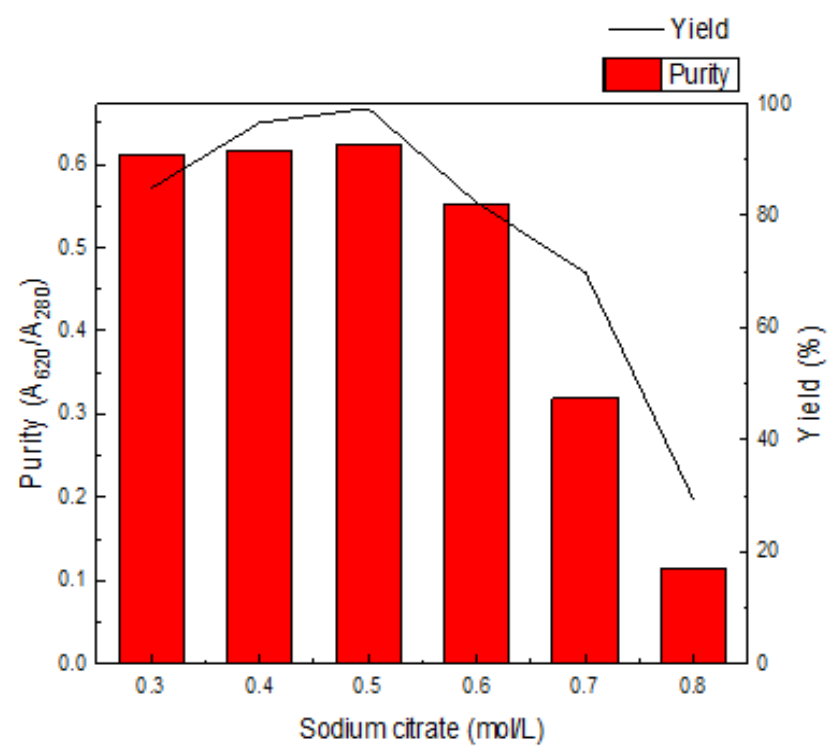

Figure 5. Effect of molar concentration of sodium citrate on purity and yield of C-phycocyanin

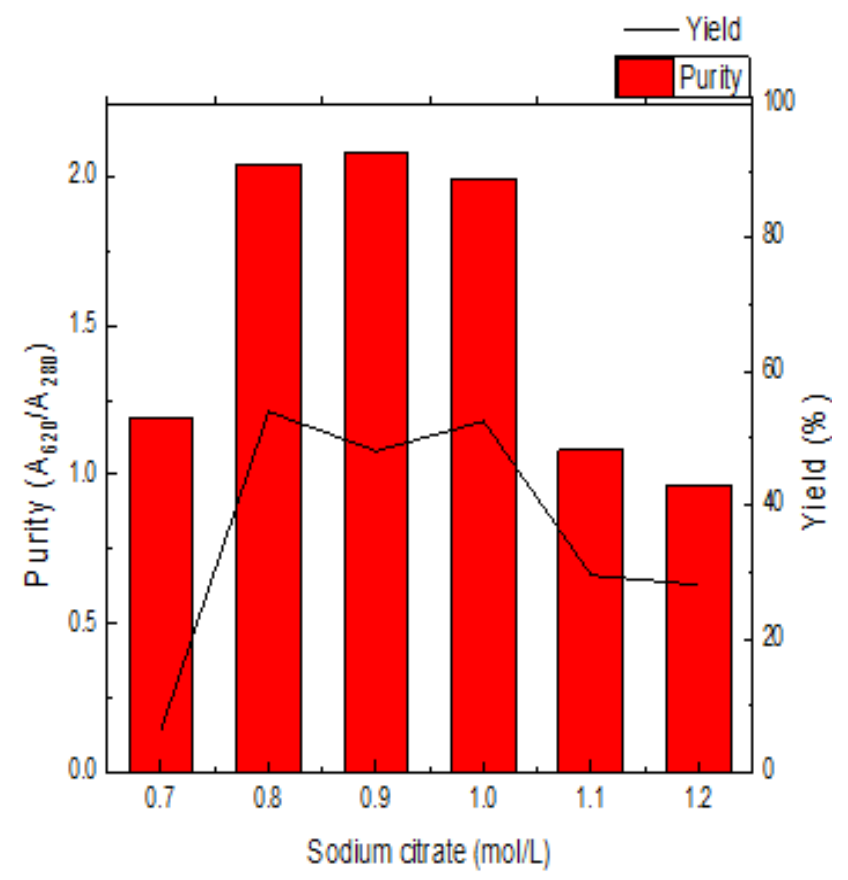

Figure 6. Influence of different molar concentration of sodium citrate in the two-step salting-out on purity and yield of phcocyanin

In the range of $0.8 \sim 1.0 \mathrm{~mol} / \mathrm{L}$ both purity and yield of phycocyanin remain unchanged, but when the concentration increased to 1.1 and $1.2 \mathrm{~mol} / \mathrm{L}$, the purity and the yield began to decline. At $0.9 \mathrm{~mol} / \mathrm{L}$, the purity reached a maximum value of 2.07 and the yield was $48 \%$, resulting in an optimal condition for the extraction of PC at $0.9 \mathrm{~mol} / \mathrm{L}$.

\subsection{Sodium Sulfate}

\subsubsection{One-step of Salting Out}

In the range of $0.95 \sim 1.20 \mathrm{~mol} / \mathrm{L} \mathrm{Na}_{2} \mathrm{SO}_{4}$ concentration, a one-step salting out process was performed according to the precipitation method to determine the purity and the yield of phycocyanin in the supernatant as shown in Figure 7. 
When the concentration was 1.0 , the purity reached the maximum of 0.3782 and the yield was $84 \%$. Between $1.05 \sim 1.2 \mathrm{~mol} / \mathrm{L}$, the purity and yield of the phycocyanin continually decreased as the concentrations were increased. The optimal conditions for the extraction of phycocyanin were $1.0 \mathrm{~mol} / \mathrm{L}$.

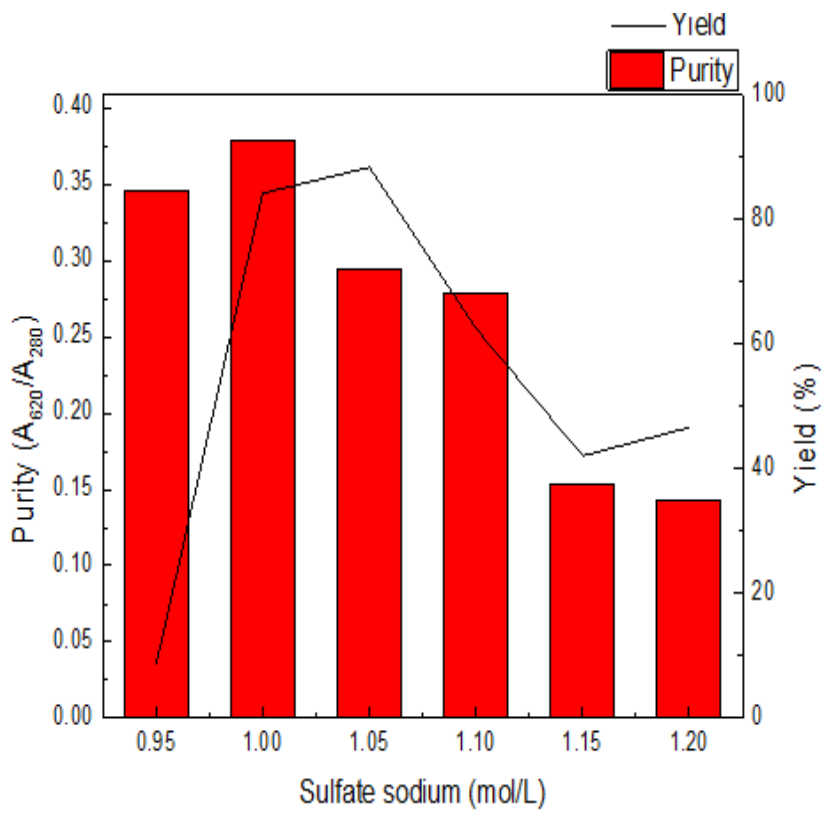

Figure 7. Effect of molar concentration of sodium sulfate on purity and yield of C-phycocyanin

\subsubsection{Two-step of Salting out}

On the basis of one-step salting process, in the range of 1.2 1.7 $\mathrm{mol} / \mathrm{L} \mathrm{Na}_{2} \mathrm{SO}_{4}$ concentration, the experiment was carried out in accordance with the precipitation method to obtain phycocyanin precipitation through dissolution and determine the purity and yield of phycocyanin as shown in Figure 8.

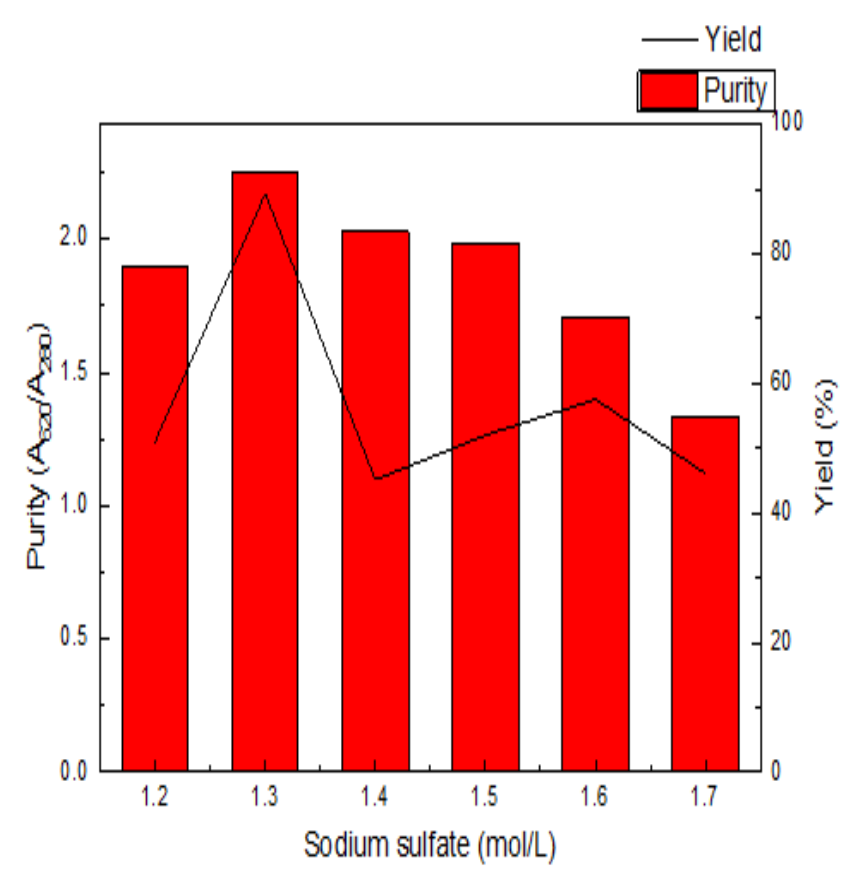

Figure 8. Influence of different molar concentration of sodium sulfate in the second step salting-out on purity and yield of phcocyanin.
In the range of $1.4 \sim 1.7 \mathrm{~mol} / \mathrm{L}$, the purity slowly decreased and the yield increased first then proceed to decrease. At $1.3 \mathrm{~mol} / \mathrm{L}$, the purity and yield reached their peak of 2.25 and $89 \%$ respectively. The optimal conditions for the extraction of phycocyanin were $1.3 \mathrm{~mol} /$ From the One-step salting out, it was observed that low concentrations of $\left(\mathrm{NH}_{4}\right)_{2} \mathrm{SO}_{4}, \mathrm{C}_{6} \mathrm{H}_{17} \mathrm{~N}_{3} \mathrm{O}_{7}, \mathrm{C}_{6} \mathrm{H}_{5} \mathrm{Na}_{3} \mathrm{O}_{7}$ and $\mathrm{Na}_{2} \mathrm{SO}_{4}$ can remove some impurities, making the purity of phycocyanin slightly increased, but inevitably causing a certain degree of loss of phycocyanin. In the two-step, it was observed that higher molar concentrations of $\left(\mathrm{NH}_{4}\right)_{2} \mathrm{SO}_{4}$, $\mathrm{C}_{6} \mathrm{H}_{17} \mathrm{~N}_{3} \mathrm{O}_{7}, \mathrm{C}_{6} \mathrm{H}_{5} \mathrm{Na}_{3} \mathrm{O}_{7}$ and $\mathrm{Na}_{2} \mathrm{SO}_{4}$ can remove impurities in large quantities, thus increasing purity and yield of phycocyanin. However, the excessive molar concentration will cause other substances to precipitate out as well, making the purity of phycocyanin to decline.

\section{Conclusion}

The current study describes a complete strategy to purify C-phycocyanin from Chaohu algae by various salting out methods. During this study, a systematic approach was used to find the optimized conditions to purify phycocyanin. With the fresh cyanobacteria with a water content of $96 \%$; the $\left(\mathrm{NH}_{4}\right)_{2} \mathrm{SO}_{4}$ concentration of 1.0 and $1.7 \mathrm{~mol} / \mathrm{L} ; \mathrm{C}_{6} \mathrm{H}_{17} \mathrm{~N}_{3} \mathrm{O}_{7}$ concentration of $0.7 \mathrm{~mol} / \mathrm{L}$ and $1.3 \mathrm{~mol} / \mathrm{L}$;, $\mathrm{C}_{6} \mathrm{H}_{5} \mathrm{Na}_{3} \mathrm{O}_{7}$ concentration 0.5 and $0.9 \mathrm{~mol} / \mathrm{L}$ and $\mathrm{Na}_{2} \mathrm{SO}_{4}$ concentration 1.0 and $1.3 \mathrm{~mol} / \mathrm{L}$, can be chosen, respectively for the one-step and two-step salting out. Salting out method proved to be a promising purification method for the C-phycocyanin, and it can be found that after two-step salting, both the purity and yield of phycocyanin suddenly increased.

\section{Acknowledgments}

The authors would like to thank Ampadu Seth and for his valuable comments that greatly improved the manuscript. Also, gratitude to all colleagues for their invaluable help and companionship while performing this study.

\section{Highlights}

- Using $\left(\mathrm{NH}_{4}\right)_{2} \mathrm{SO}_{4}$ Cyanobacterialphycocyaninwere finally obtained with a purity value of 2.0 with a recovery rate of $35 \%$

- Using $\mathrm{C}_{6} \mathrm{H}_{17} \mathrm{~N}_{3} \mathrm{O}_{7}$ Cyanobacterial phycocyaninwere finally obtained with a purity value of 2.27 with 91\% recovery of Cyanobacterialphycocyanin

- Using $\mathrm{C}_{6} \mathrm{H}_{5} \mathrm{Na}_{3} \mathrm{O}_{7}$ Cyanobacterialphycocyaninwere finally obtained with a purity value of 2.07 with $48 \%$ recovery of Cyanobacterialphycocyanin

- Using $\mathrm{Na}_{2} \mathrm{SO}_{4}$. Cyanobacterial phycocyaninwere finally obtained with a purity value of 2.25 with $89 \%$ recovery of Cyanobacterialphycocyanin.

\section{Abbreviations}

$\alpha$ Light polypeptides 


$\begin{array}{ll}\beta & \text { Heavy polypeptides } \\ \mathrm{BGA} & \text { Blue green algae } \\ \mathrm{C}_{6} \mathrm{H}_{17} \mathrm{~N}_{3} \mathrm{O}_{7} & \text { Triammonium citrate } \\ \mathrm{C}_{6} \mathrm{H}_{5} \mathrm{Na}_{3} \mathrm{O}_{7} & \text { Sodium citrate } \\ \mathrm{C}-\mathrm{PC} & \text { C-Phycocyanin } \\ \text { Eq. } & \text { Equation } \\ \text { Fig. } & \text { Figure } \\ \mathrm{g} & \text { Gram } \\ \mathrm{kDa} & \text { Kilodaltons } \\ \mathrm{kmax} & \text { Absorption peak } \\ \mathrm{L} & \text { Liter } \\ \mathrm{Min} & \text { Minute } \\ \mathrm{mM} & \text { Millimol } \\ \mathrm{mol} / \mathrm{L} & \text { Mol per Liter } \\ \mathrm{MW} & \text { Molecular Weight } \\ \mathrm{Na} \mathrm{S}_{4} & \text { Sodium sulfate } \\ (\mathrm{NH})_{2} \mathrm{SO}_{4} & \text { Ammonium sulphate } \\ \mathrm{nm} & \text { Nanometer } \\ \mathrm{P} & \text { Purity } \\ \mathrm{PBP} & \text { Phycobiliproteins } \\ \mathrm{PC} & \text { Phycocyanin } \\ {[\mathrm{PC}]_{0}} & \text { Mass concentration of phycocyanin crude extract } \\ \mathrm{pH} & \text { Potential Hydrogen } \\ \mathrm{R} & \text { Recovery } \\ \mathrm{Vt} & \text { Phycocyanin volume } \\ \mathrm{V} & \text { Volume of crude extract from phycocyanin. } \\ { }^{\circ} \mathrm{C} & \text { Celsius degree } \\ () & \text { Bracket } \\ \% & \text { Percent } \\ / & \text { Per } \\ \sim & \text { To } \\ & \end{array}$

\section{References}

[1] Kibria, G., (2016). Blue-green algal/cyanobacterial blooms (BGA), climate change and BGA impacts on water quality, fish kills, recreation, crops, seafood, livestock, wild animals and humans, 1-7.

[2] Devendra; Dolly; Sunil; Neeraj, and Suresh, (2014). Extraction and purification of C-phycocyanin from Spirulinaplatensis (CCC540) Indian J. Plant Physiol., 19: 184-188.

[3] Reis, A.; Mendes, A.; Lobo-Fernandes, H.; Empis, J.A.; Novais, J.M., (1998). Production, extraction and purification of phycobiliproteins from Nostoc sp. Bioresour. Technol. 66: 181-187.

[4] Sonani, R.R.; Singh, N.K.; Kumar, J.; Thakar, D.; Madamwar, D., (2014). Concurrent purification and antioxidant activity of phycobiliproteins from Lyngbya sp. A09DM: an antioxidant and anti-aging potential of phycoerythrin in Caenorhabditiselegans. Process Biochem., 49:1757-1766.

[5] Bermejo, R.; Acién, F.G.; Ibanez, M.J.; Fernandez, J.M.; Molina, E.; Alvarez-Pez, J.M., (2003). Preparative purification of Bphycoerythrin from the microalga Porphyridiumcruentum by expanded-bed adsorption chromatography. J. Chromatogr. B. 790: 317-325.

[6] Khattar, J.I.S.; Kaur, S.; Kaushal, S.; Singh, Y.; Singh, D.P.; Rana, S.; Gulati, A., (2015). Hyperproduction of phycobiliproteins by the cyanobacterium Anabaenafertilissima PUPCCC 410.5 under optimised culture conditions. Algal Res., 12: 463-469.

[7] Singh, N.K.; Parmar, A.; Madamwar, D., (2009). Optimisation of medium components for increased production of C-phycocyanin from Phormidiumceylanicum and its purification by single step process. Bioresour. Technol., 100: 1663-1669.

[8] Klotz, A.V.; Glazer, A.N.; Bishop, J.E.; Nagy, J.O.; Rapoport, H., (1986). Phycobiliprotein-bilin linkage diversity. II. Structural studies on A and D-ring-linkedphycoerythrobilins. J. Biol. Chem., 261: 6797-6805.

[9] Apt, K.E.; Collier, J.L.; Grossman, A.R., (1995). Evolution of the phycobiliproteins. J.Mol. Biol., 248: 79-96.
[10] Glazer, A.N.; Fang, S.; Brown, D.M.,(1973). Spectroscopic properties of C-phycocyanin and of its a and b subunits. J. Biol. Chem., 248: 5679-5685.

[11] Sekar, S.; Chandramohan, M., (2008). Phycobiliproteins as a commodity: trends in applied research, patents and commercialization. J. Appl. Phycol., 20:113-136.

[12] Qureshi, M.A.; Garlich, J.D., \& Kidd, M.T., (1996). Dietary Spirulinaplatensis enhances humoral and cell-mediated immune functions in chickens. Immunopharmacol. Immunotoxicol., 18: 465-476.

[13] Romay, C.; Gonzalez, R., (2000). Phycocyanin is an antioxidant protector of human erythrocytes against lysis by peroxyl radicals. J. Pharm. Pharmacol., 52:367-368.

[14] Cherng, S.C.; Cheng, S.N.; Atarn C.T.C., (2007). Antiinflammatory activity of C-phycocyanin in lipopolysaccharidestimulated RAW264. 7 macrophages. Life Sci., 81:1431-1435.

[15] Eriksen, N.T., (2008). Production of phycocyanina pigment with applications in biology, biotechnology, foods and medicine. Appl. Microbiol. Biotechnol., 80: 1-14.

[16] Chaiklahan, R.; Chirasuwan, N.; Loha, V.; Tia, S.; Bunnag, B., (2011). Separation and purification of phycocyanin from Spirulinasp. using a membrane process. Bioresour. Technol., 102:7159-7164.

[17] Kuddus, M.; Singh, P.; Thomas, G.; Al-Hazimi, A., (2013) Recent developments in production and biotechnological applications of C-phycocyanin. Biomed. Res. Int., 1-10.

[18] Roman, R.B.; Alvarez-Pez, J.M.; Acien Fernandez, F.G.; Grima, E.M., (2002). Recovery of pure B-PE from the microalgae Porphyriumcruenlum. J. Biotechnol., 93: 73-85.

[19] Rassano, R.; Ungaro, N.; D’Ambariso, A.; Liuzzi, G.M.; Riccio, P., (2003). Extractingandpurifying RPE frommediterranean red algaeCorallinaelongata Ellis andSolander. J. Biotechnol., 101: 289-293.

[20] Vonshak, A., (1997). Spirulinaplatensis (Arthospira): Physiology, cell biology and biotechnology. Taylor \& Francis, London.

[21] Boussiba, S.;\& Richmond, A. E., (1979). Isolation and characterization of phycocyanins from the blue-green alga Spirulinaplatensis. Arch. Microbiol., 120: 155-159.

[22] Hirata, T.; Tanaka, M.; Ooike, M.; Tsunomura, T.; Sakaguchi, M. (2000). Antioxidant activities of phycocyanobilin prepared from Spirulinaplatensis. J. Appl. Phycol., 12: 435-439.

[23] Minkova, K. M.; Tchernov, A.A.; Tchorbadjieva, M.I.; Fournadjieva, S.T.; Antova, R.E.; Busheva, M.C., (2003) Purification of C-phycocyanin from Spirulina (Arthrospira) fusiformis. J. Biotechnol., 102: 55-59.

[24] Yan, S.; Zhu, L.; Su, H.; Zhang, X.; Chen, X.; Zhou, B.; Zhang, Y., (2011). Single-step chromatography for simultaneous purification of C-phycocyanin and allophycocyanin with high purity and recovery from Spirulina (Arthrospira) platensis. J. Appl. Phycol., 23: 1-6.

[25] Ferreira, H.A.; Torres, D.P.V., and Juarez-Oropeza, M.A., (2010). Hepatoprotective effects of Spirulinamaximain patients with nonalcoholic fatty liver disease: a case series. J. Med. Case Rep., 4: $1-5$.

[26] Gantar, M.;Simovic, D.; Djils, S.; Gonzalez, W.W., and Miksovska, J., (2012). Isolation, characterization and antioxidative activity of C-phycocyanin from Limnothrixsp. Strain 37-2-1. J. Biotechnol., 159: 21-26.

[27] Deng, R., and Chow, T.J., (2010). Hypolipidemic, antioxidant and anti-inflammatory activities of microalgae Spirulina. Cardiovasc. Ther., 28: 33-45.

[28] Reddy, M.C.; Subhashini, J.; Mahipal, S.V.K.; Bhat, V.B.; Reddy, P.S.; Kiranmai, G.; Madyastha, K.M.; Reddanna, P., (2003). CPhycocyanin,a selective cyclooxygenase-2 inhibitor, induces $\begin{array}{lll}\text { apoptosis in lipopolysaccharide-stimulated RAW } 264.7 & 0\end{array}$ macrophages. Biochem. Biophys. Res. Commun., 304: 385-392.

[29] Soni, B.;Kalavadia, B.; Trivedi, U.; Madamwar, D., (2006). Extraction, purification and characterization of phycocyanin from Oscillatoria quadripunctulata Isolated from the rocky shores of Bet-Dwarka, Gujarat, India. Process Biochem., 41: 2017-2023.

[30] Niu, J.F.; Wang, G.C.; Tseng, C.K., (2006). Method for LargeScale Isolation and Purification of R-Phycoerytrin Red Alga Polysiphoniaurceolata Grev. Protein Expression Purif., 49: 23-31.

[31] Moraes, C.; Sala, L.; Cerveira, G.P.;Kalil, S.J., (2011). C-Phycocyanin extraction from Spirulinaplatensis wet biomass. Braz. J. Chem. Eng., 28: 45-48. 
[32] Zhang, F.; Yu, J.; Zhang, L.; Sheng, J.; Wang, J., (2017). Ultraviolet-Visible absorption spectra characteristics analysis of cyanophycocyanin from Chaohu Lake during the purification process. J. Spectrosc. Spect. Anal., 37: 806-810.

[33] Herrera, A.;Boussiba, S.;Hohlberg, A.; Napoleone, V. (1989). Recovery of c-phycocyanin from the cyanobacterium Spirulinamaxima. J. Appl. Phycol. 1: 325-331.
[34] MacColl, R., (1998). Cyanobacterialphycobilisomes. J. Struct. Biol., 124: 311-334.

[35] Yuan Meng Yuan. Zhang Fayu. Sheng Jing Meng. Lu Yi Nan. Wang Jiaquan (2016). Food science and Technology. 41. (5) 267-272. 